\title{
Acute intravascular hemolysis due to naphthalene toxicity: a case report
}

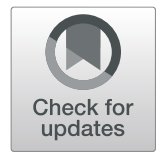

\author{
A. A. A. Uthuman ${ }^{*}$, C. S. Jayasinghe and A. H. N. Fernando
}

\begin{abstract}
Background: Naphthalene (mothball) is a commonly used deodorizer in the Indian subcontinent, including Sri Lanka. Though it is freely available around this country, poisoning has never been reported in the literature. Ingestion, either accidental or by deliberate self-harm, can occur due to its abundance as well as its candy-resembling appearance.

Case Presentation: A 33-year-old Sri Lankan woman presented to us 2 days after the self-ingestion of 15 naphthalene balls. She had features of intravascular hemolysis without features of pigment nephropathy or methemoglobinemia. She was symptomatically managed with blood transfusion and adequate hydration.

Conclusion: Naphthalene ingestion can lead to severe intravascular hemolysis as well as methemoglobinemia. The resultant pigment nephropathy may also lead to acute kidney injury.
\end{abstract}

Keywords: Naphthalene, Mothball, Acute intravascular hemolysis

\section{Introduction}

Naphthalene, a simple polycyclic aromatic hydrocarbon, is commonly used as a deodorizer and moth repellent in the Indian subcontinent, including Sri Lanka. It is widely available in all grocery shops, street shops, and supermarkets. A mothball has the size of a jellybean, with its shiny and whitish appearance making it susceptible for accidental ingestion, mainly by children. The lethal dose of acute naphthalene toxicity is $5-15 \mathrm{~g}$ for adults and $2-3 \mathrm{~g}$ for children [1], with the standard weight of one mothball being $4 \mathrm{~g}$. Overdose, either accidental or deliberate ingestion, can lead to a myriad of clinical manifestations, including hemolysis [2]. In Sri Lanka, there are no previously reported cases of naphthalene poisoning. Herein, we report on a patient with deliberate self-harm ingestion of 15 mothballs leading to severe hemolytic anemia warranting blood transfusion.

\section{Case Presentation}

A 33-year-old married Sri Lankan woman presented with an episode of sudden onset of dark-colored urine with the background history of self-ingestion of 15

\footnotetext{
* Correspondence: aliakram20@gmail.com

The National Hospital of Sri Lanka, Colombo, Sri Lanka
}

mothballs 2 days prior. This was an impulsive attempt after a quarrel with her husband. She denied co-ingestion of other substances including pharma ceuticals.

There was no significant complaint other than malaise and mild epigastric pain. She did not have features suggestive of urinary tract infection. Her past medical history, including history of hereditary hemolytic anemias, was unremarkable. She was not on any routine medications. Examination revealed severe pallor with lemon tinge icterus. Abdominal examination was normal, and other systemic examination was unremarkable.

Her clinical test revealed severe normochromic normocytic anemia with a hemoglobin level of $5.9 \mathrm{~g} / \mathrm{dL}$ and a reticulocyte index of 2.36 with indirect hyperbilirubinemia. Her blood picture featured normochromic normocytic red cells with reduced count, blister cells, bite cells, and red cell fragments suggestive of intravascular hemolysis (Fig. 1). Other investigations, including arterial blood gas are shown in Tables 1 and 2. As she had normal oxygen saturation and partial pressure, plasma methemoglobin levels were not measured.

She was hydrated adequately with monitoring of urinary output as well as serum creatinine. During hospital stay, she was transfused with two packs of red cell 


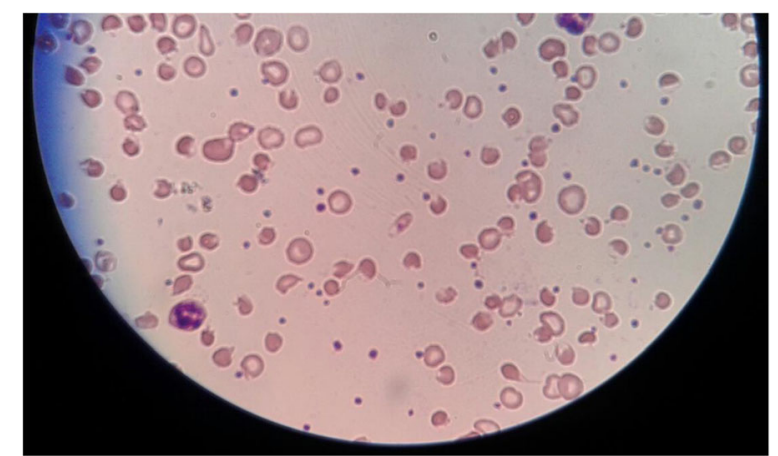

Fig. 1 Acute intravascular hemolysis showing blister cells, bite cells, and red cell fragments concentrate. Over a week, the hemoglobin levels increased and hemolysis settled. She never went into acute kidney injury. A review after 4 weeks revealed a hemoglobin level of $12.1 \mathrm{~g} / \mathrm{dL}$ and she was symptom free.

\section{Discussion}

Naphthalene $\left(\mathrm{C}_{10} \mathrm{H}_{8}\right)$ is a volatile polycyclic hydrocarbon used as a deodorizer and moth repellent in households. Toxic effects had been reported through various modes of exposure, including inhalation, external skin contact, and ingestion [3]. Myriads of clinical manifestations have been reported, yet few have been tabulated [4] (Table 3).

Its toxic manifestations are mainly due to production of oxygen free radicals leading to lipid peroxidation and deoxyribonucleic acid (DNA) damage [5]. Hemolysis occurs usually in susceptible individuals such as in those who are G6PD deficient. In addition to hemolysis, due to its potent oxidizing property, it converts hemoglobin to methemoglobin, leading to methemoglobinemia [6]; therefore, the presence of cyanosis with normal oxygen saturation in arterial blood gas should raise the suspicion of methemoglobinemia.

Table 1 Sequential value of laboratory parameters during hospital stay

\begin{tabular}{lcllll}
\hline & Day 1 & Day 2 & Day 3 & Day 6 & Day 8 \\
\hline $\mathrm{Hb}(\mathrm{g} / \mathrm{dL})$ & 8.0 & 6.6 & 6.0 & 10.1 & 10.4 \\
Total bilirubin $(\mu \mathrm{mol} / \mathrm{L})$ & & 250.5 & 88.9 & 27.2 & 24 \\
Direct bilirubin $(\mu \mathrm{mol} / \mathrm{L})$ & & 10.7 & 9.5 & 4.6 & 7.6 \\
Creatinine $(\mu \mathrm{mol} / \mathrm{L})$ & & 67 & 58 & 47 & 67 \\
\hline
\end{tabular}

Abbreviations: $H B$ Hemoglobin
Table 2 Arterial blood gas

\begin{tabular}{ll}
\hline $\mathrm{pH}$ & 7.417 \\
$\mathrm{pCO}_{2}$ & $32.5 \mathrm{mmHg}$ \\
$\mathrm{pO}_{2}$ & $114.2 \mathrm{mmHg}$ \\
$\mathrm{SaO}_{2}$ & $96.8 \%$ \\
\hline
\end{tabular}

Abbreviations: $p \mathrm{CO}_{2}$ Partial pressure of carbon dioxide, $p \mathrm{O}_{2}$ Partial pressure of oxygen, $\mathrm{SaO}_{2}$ Arterial oxygen saturation

Significant intravascular hemolysis gives rise to hemoglobinuria due to resultant saturation of hemoglobin scavengers such as haptoglobin. This may lead to acute kidney injury due to tubular precipitation of free hemoglobin [7], which was not seen in our patient. Hemolysis usually starts by the second day of exposure and can be protracted up until a week. Therefore, screening for hemolysis should continue until a week of post-exposure [8]; however, in this case, the patient presented with hemolysis features on the second day of ingestion.

A fall in hemoglobin and hematocrit levels with a high reticulocyte index, as well as spherocytosis and Heinz bodies in blood picture denote hemolysis. Unconjugated hyperbilirubinemia as well as high lactate dehydrogenase would also be found. Our patient's smear revealed blister cells, bite cells, and red cell fragments (Fig. 1). Pigment nephropathy and acute kidney injury were prevented by adequate hydration and urine alkalization.

With regards to methemoglobinemia, the antidote would be methylene blue. However, an urgent G6PD enzyme assay is indispensable prior to the administration of methylene blue as it can paradoxically cause methemoglobinemia in G6PD-deficient patients [9].

Table 3 Systemic effects of naphthalene exposure

Gastrointestinal effects

Nausea, vomiting, abdominal pain, diarrhea

Renal effects

Increased creatinine level, increased serum urea nitrogen level, hematuria, renal tubular acidosis

Respiratory effects

Congestion, Acute Respiratory Distress Syndrome (noted at 2 ppm) Neurologic effects

Confusion, lethargy, vertigo, fasciculations, convulsions, anesthesia, cerebral edema, coma (coma is noted at $0.05 \mathrm{mg} / \mathrm{kg}$ body weight per day)

Hepatic effects

Jaundice, hepatomegaly, elevated liver enzyme levels (noted at $0.02 \mathrm{mg} / \mathrm{kg}$ per day)

Ocular effects

Optic atrophy, bilateral cataracts with chronic exposure 


\section{Conclusion}

Naphthalene overdose can lead to severe intravascular hemolysis as well as methemoglobinemia. Both are potentially treatable when diagnosed promptly. Complications such as acute kidney injury could be prevented by meticulous fluid management and urinary alkalization. As it is extremely common in households, physicians should be aware of the toxidrome of naphthalene poisoning.

\section{Acknowledgements}

This case report was supported by doctors working in ward 47B, The National Hospital of Sri Lanka, for the acquisition, analysis, and interpretation of data. We are thankful to the patient's relatives for the support given in providing data.

\section{Funding}

No source of funding.

\section{Availability of data and materials}

The datasets supporting the conclusions of this article are included within the article.

\section{Authors' contributions}

AUAA collected data, followed up the patient, performed the literature review, and drafted the manuscript. CSJ assisted in data collection and patient follow-up. AHNF drafted and corrected the manuscript. All authors read and approved the final manuscript.

\section{Ethics approval and consent to participate}

Not applicable.

\section{Consent for publication}

Written informed consent was taken from the patient for publication of this case report. A copy of the written consent is available for review by the Editor-in-Chief of this journal.

\section{Competing interests}

The authors declare that they have no competing interests.

\section{Publisher's Note}

Springer Nature remains neutral with regard to jurisdictional claims in published maps and institutional affiliations.

Received: 8 September 2018 Accepted: 20 December 2018

Published online: 22 March 2019

\section{References}

1. Faust RA PhD. Formal Toxicity Summary for NAPTHALENE. [cited $2018 \mathrm{Sep}$ 8]. Available from: https://rais.ornl.gov/tox/profiles/naphthalene_f_V1.html.

2. Kundra TS, Bhutatani V, Gupta R, Kaur P. Naphthalene Poisoning following Ingestion of Mothballs: A Case Report. J Clin Diagn Res. 2015;9(8):UD01-2.

3. Nte A, Anochie I, Eke F. Naphthalene poisoning in children: a report of two cases. Nigerian J Paediatrics. 2006;33(2):60-3.

4. Naphthalene; CASRN 91-20-3. U.S. Environmental Protection Agency, National Center for Environmental Assessment. Available from: https:/cfpub.epa.gov/ncea/ iris/iris documents/documents/subst/0436 summary.pdf. Accessed 11 Jan 2019.

5. Bagchi M, Bagchi D, Balmoori J, Ye X, Stohs SJ. Naphthalene-induced oxidative stress and DNA damage in cultured macrophage J774A.1 cells. Free Radic Biol Med. 1998;25(2):137-43.

6. Deo P, Sahu KK, Dhibar DP, Varma SC. Naphthalene ball poisoning: a rare cause of acquired methaemoglobinaemia. BMJ Case Reports. 2016;2016:bcr2016215102

7. Kapoor R, Suresh P, Barki S, Mishra M, Garg MK. Acute intravascular hemolysis and methemoglobinemia following naphthalene ball poisoning. Indian J Hematol Blood Transfus. 2014;30(1):317-9.

8. Aliyu I, Ibrahim ZF. Haemolytic anemia and mothball toxicity: a case report Sifa Med J. 2014;1(3):39-41

9. Rosen PJ. Failure of methylene blue treatment in toxic methemoglobinemia. Ann Int Med. 1971;75(1):83-6.
Ready to submit your research? Choose BMC and benefit from:

- fast, convenient online submission

- thorough peer review by experienced researchers in your field

- rapid publication on acceptance

- support for research data, including large and complex data types

- gold Open Access which fosters wider collaboration and increased citations

- maximum visibility for your research: over $100 \mathrm{M}$ website views per year

At $\mathrm{BMC}$, research is always in progress.

Learn more biomedcentral.com/submissions 